\title{
TET Proteins and 5-Methylcytosine Oxidation in the Immune System
}

\author{
Ageliki Tsagaratou ${ }^{1}$ and Anjana RaO ${ }^{1,2,3,4}$ \\ ${ }^{1}$ La Jolla Institute for Allergy and Immunology, La Jolla, California 92037 \\ ${ }^{2}$ Department of Pharmacology, University of California, San Diego, La Jolla, California 92093-0636 \\ ${ }^{3}$ Sanford Consortium for Regenerative Medicine, La Jolla, California 92037 \\ ${ }^{4}$ Correspondence: arao@liai.org
}

\begin{abstract}
DNA methylation in the form of 5-methylcytosine $(5 \mathrm{mC})$ is essential for normal development in mammals and influences a variety of biological processes, including transcriptional regulation, imprinting, and the maintenance of genomic stability. The recent discovery of TET proteins, which oxidize $5 \mathrm{mC}$ to 5-hydroxymethylcytosine, 5-formylcytosine, and 5-carboxylcytosine, has changed our understanding of the process of DNA demethylation. Here, we summarize our current knowledge of the roles of DNA methylation and TET proteins in cell differentiation and function. The intensive research on this subject has so far focused primarily on embryonic stem (ES) cells and neurons. In addition, we summarize what is known about DNA methylation in T-cell function.
\end{abstract}

Methylation of cytosines in metazoan genomes adds epigenetic information onto DNA without changing the genetic information encoded in the DNA sequence. Until recently, the only known modified base in DNA was 5methylcytosine $(5 \mathrm{mC})$, an epigenetic mark established by DNA methyltransferases (DNMTs) (Ooi et al. 2009). In somatic cells, $5 \mathrm{mC}$ is almost exclusively found in the $\mathrm{CpG}$ sequence context, although non-CpG methylation has been documented in embryonic stem (ES) cells and in neurons (Lister et al. 2009, 2013). The promoters of the most highly expressed genes show the lowest levels of CpG methylation; conversely, dense CpG methylation of promoters is generally associated with decreased gene expression (Suzuki and Bird 2008; Laurent et al. 2010; Deaton and Bird 2011). There is also dense DNA methylation in gene bodies (Lister et al. 2009; Laurent et al. 2010), but the association of gene body CpG methylation with transcriptional regulation is less clear.

Two classes of DNMTs are involved in DNA methylation. The de novo DNA methyltransferases DNMT3A and $3 \mathrm{~B}$ are required to establish DNA methylation patterns, whereas the maintenance DNA methyltransferase, DNMT1, reestablishes DNA methylation patterns following DNA replication (Klose and Bird 2006; Ooi et al. 2009). DNMT1 acts with its cofactor UHRF1, which binds hemimethylated DNA (Avvakumov et al. 2008; Hashimoto et al. 2008), to reestablish symmetrical CpG methylation on the newly synthesized DNA strand, thus maintaining DNA methylation patterns during replication (Bestor et al. 1988; Ooi et al. 2009).

The distribution of $5 \mathrm{mC}$ has been mapped at singlenucleotide resolution in human and mouse ES cells, ES cells differentiated to distinct lineages, somatic tissues, cultured cell lines, and various cancer cells (Hansen et al. 2011; Stadler et al. 2011; Kulis et al. 2012; Gifford et al. 2013; Lister et al. 2013; Xie et al. 2013; Ziller et al. 2013). These studies showed that most of the genome is highly methylated ( $\sim 80 \%-90 \%$ of CpGs with $>50 \%$ methylation), with the remainder subdivided into unmethylated regions (UMRs) with $<10 \%$ methylation and lowmethylated regions (LMRs) with 10\%-50\% methylation (Stadler et al. 2011). UMRs correspond largely to unmethylated $\mathrm{CpG}$ islands (CGIs), many of which are located at transcription start sites (TSSs), whereas LMRs often coincide with promoter-distal gene regulatory elements enriched for transcription factor-binding sites (Stadler et al. 2011).

\section{TET PROTEINS ARE 5mC OXIDASES}

The recent discovery that TET (ten-eleven translocation) proteins are $5 \mathrm{mC}$ oxidases added an additional layer of complexity to our understanding of the biological role of DNA methylation (Iyer et al. 2009; Tahiliani et al. 2009). TET proteins are named after the rare ten-eleven translocation $(\mathrm{t}(10 ; 11)(\mathrm{q} 22 ; \mathrm{q} 23))$ observed in cases of acute myeloid and lymphocytic leukemia, in which the MLL1 (mixed-lineage leukemia 1) gene located on human chromosome 10 is fused with the TET1 gene located on chromosome 11 (Ono et al. 2002; Lorsbach et al. 2003). The three TET proteins in mammals, TET1, TET2, and TET3 (Fig. 1A), were identified by homology with the J-binding proteins (JBPs) of trypanosomes (Iyer et al. 2008) and are members of the larger TET-JBP family of 2-oxoglutarate- and Fe(II)-dependent dioxygenases (Loenarz and Schofield 2008, 2011; Iyer et al. 2009; Tahiliani et al. 2009). JBP1 and JBP2 oxidize the methyl group 
A

A TET
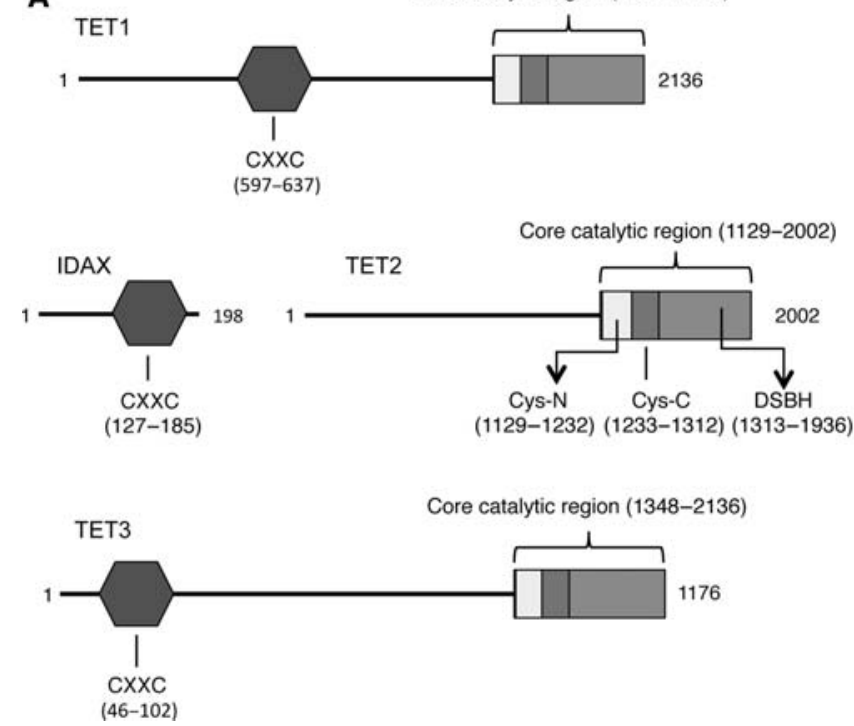

B
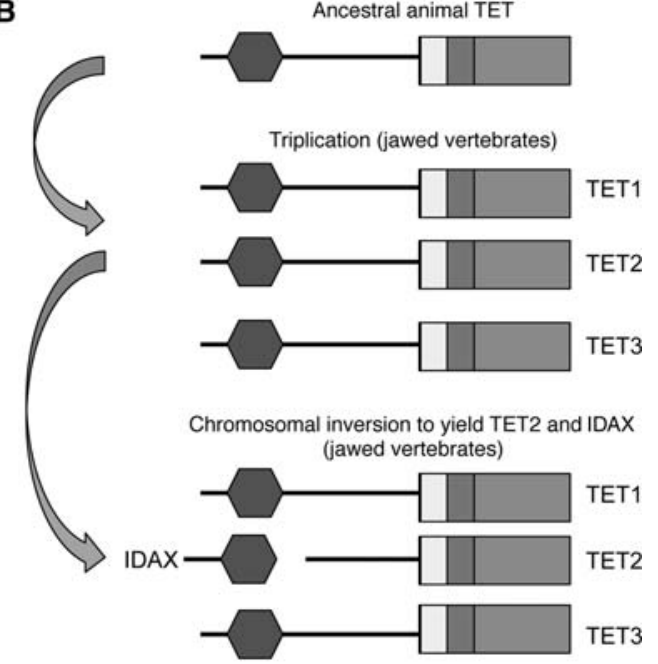

Figure 1. (A) Schematic representation of the predicted functional domains of mammalian TET proteins. Depicted is the CXXC domain that is present in TET1 and TET3, the carboxy-terminal catalytic domain that contains a cysteine-rich (Cys-rich) region, and the double-strand $\beta$-helix (DSBH) region, all three of which are common features in all three members of the TET family. The crystal structure of human TET2 reveals that the Cys-rich region is divided into amino- and carboxy-terminal regions that flank the DSBH domain (Hu et al. 2013). Also depicted is IDAX, a CXXC-domain protein that was part of TET2 before chromosomal inversion $(B)$. The numbers indicate the amino acids in human TET proteins. (B) Evolutionary history of TET proteins. The original gene encoding TET underwent triplication in jawed vertebrates, giving rise to the three members of the TET family. A subsequent chromosomal inversion resulted in the separation of the TET2 catalytic domain from the CXXC domain, which became a separate gene, IDAX/ CXXC4.

of thymine; the resulting 5-hydroxymethyluracil is then glycosylated to generate Base J (Iyer et al. 2009; Pastor et al. 2013). The mammalian TET proteins 2-oxoglutarate- and $\mathrm{Fe}$ (II)-dependent dioxygenases oxidize $5 \mathrm{mC}$ to generate $5 \mathrm{hmC}, 5 \mathrm{fC}$, and $5 \mathrm{caC}$ (Fig. $1 \mathrm{~B}$; for review, see Pastor et al. 2013) (Tahiliani et al. 2009; He et al. 2011; Ito et al. 2011). Representatives of the TET/JBP superfamily are found in every metazoan organism that uses DNA methylation (Iyer et al. 2009), suggesting a major role for TET proteins in regulating DNA methylation status through production of oxi-mC (Kohli and Zhang 2013; Pastor et al. 2013).

The prediction that the core catalytic domain of TET proteins is a double-strand $\beta$ helix (DSBH) adjacent to a unique cysteine-rich domain involved in DNA recognition (Iyer et al. 2009) was confirmed experimentally by studies on recombinant human TET1 expressed in insect cells, which showed that the DSBH region was catalytically inactive unless the Cys-rich region was present (Tahiliani et al. 2009), and subsequently by determination of the crystal structures of the human TET2 catalytic domain (Hu et al. 2013) and a TET-like dioxygenase from Naegleria gluberi (Hashimoto et al. 2013). In the human TET2 structure, the DSBH region forms the active site with the signature His-Xaa-Asp motif (where Xaa is any amino acid) and a conserved Arg residue that binds 2oxoglutarate, whereas the Cys-rich region wraps around the DSBH core and stabilizes DNA binding (Hu et al. 2013). Notably, the TET2 catalytic domain binds CpGcontaining and methyl-CpG-containing DNA with similar affinity; the fact that the methyl group itself does not contact TET2 presumably allows the catalytic cavity to accommodate the partly oxidized $5 \mathrm{mC}$, derivative $5 \mathrm{hmC}$, and $5 \mathrm{fC}$ for further oxidation to $5 \mathrm{caC}$ (Hu et al. 2013).

TET1 and TET3 contain amino-terminal CXXC domains, whereas TET2 became separated from its CXXC domain as a result of a chromosomal inversion (Fig. 1B) (Iyer et al. 2009; for review, see Pastor et al. 2013). The separated CXXC domain is now a distinct gene, IDAX (inhibition of the Dvl and axin complex; also known as CXXC4), whose product, when DNA bound, recruits TET2 and regulates TET2 protein levels through caspase activation (Ko et al. 2013). CXXC domains typically bind unmethylated $\mathrm{CpGs}$ and are found in many chromatinassociated proteins, including the maintenance methyltransferase DNMT1 and MLL1, a component of the SET/COMPASS complex.

\section{TET PROTEINS AND oxi-mC IN THE PATHWAY TO DNA DEMETHYLATION}

The oxidative derivatives of $5 \mathrm{mC}$ that are generated by TET proteins are likely to serve as intermediates in DNA demethylation (Kohli and Zhang 2013; Pastor et al. 2013). Two main pathways for demethylation have been proposed: Passive dilution of the oxidized base during DNA replication and active DNA demethylation through DNA repair (Fig. 2). We note, however, that $5 \mathrm{hmC}$ is abundant in postmitotic neurons-in Purkinje 


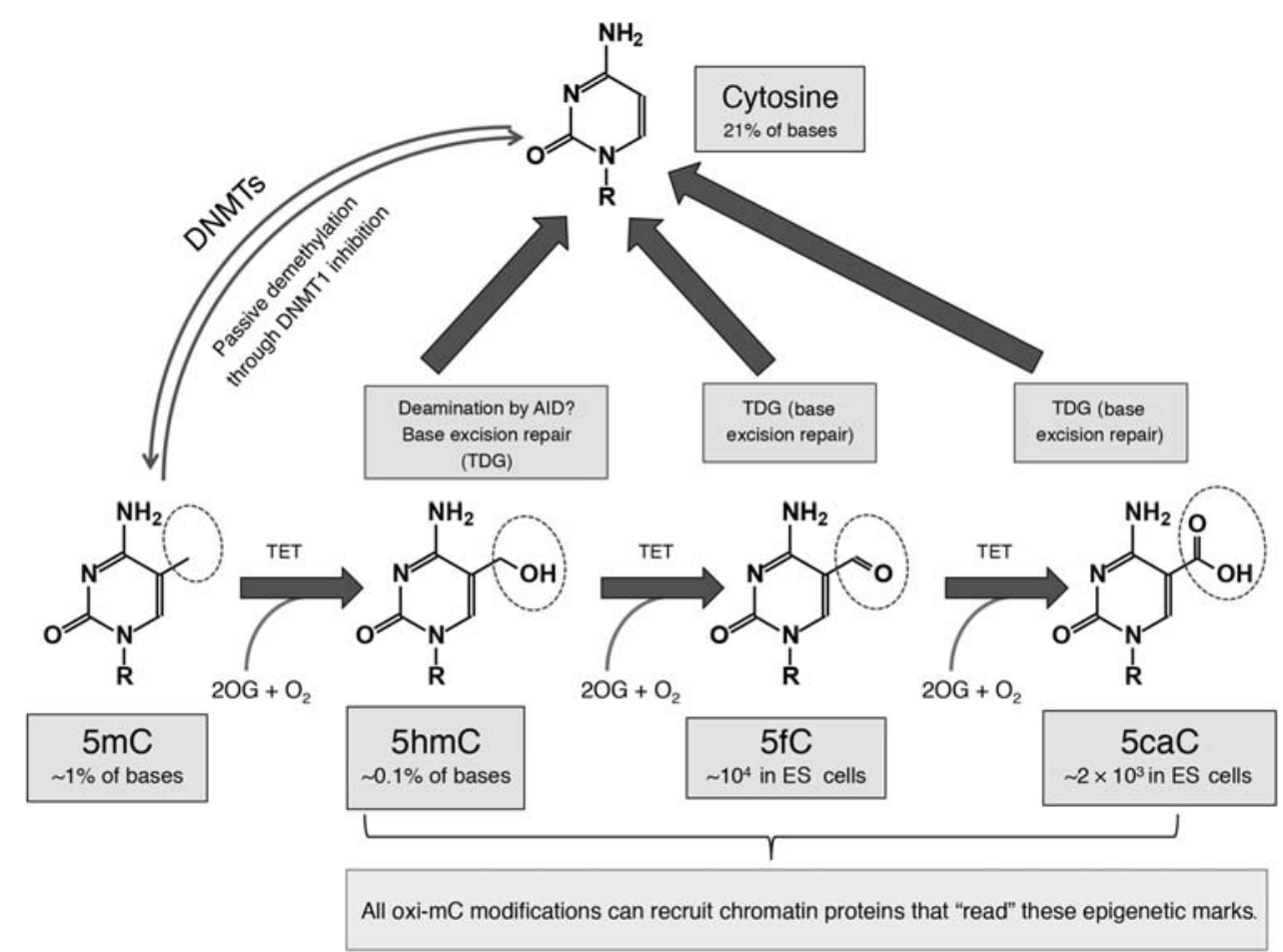

Figure 2. The cycle of DNA demethylation by TET proteins and the generation of oxi-mCs. DNA methyltransferases (DNMTs) add a methyl group to the 5 position of cytosine, and thus are responsible for DNA methylation. DNA demethylation can occur passively by inhibition of the maintenance methyltransferase DNMT1, especially in the presence of oxi-mCs, which inhibit DNMT1, resulting in dilution of the methyl mark during replication. TET proteins in the presence of 2-oxoglutarate (2OG) can oxidize $\mathrm{mC}$ to $5 \mathrm{hmC}$, which is further oxidized by the TET proteins to $5 \mathrm{fC}$ and $5 \mathrm{caC}$, which are much less abundant than $5 \mathrm{hmC}$ in the genome. $5 \mathrm{fC}$ and $5 \mathrm{caC}$ are recognized and excised by thymine DNA glycosylase (TDG) and subsequently replaced through base excision repair with unmethylated C. $5 \mathrm{hmC}$ has also been suggested to be directly demethylated by deamination through AID, followed by base excision repair mediated by TDG. Notably, the oxi-mCs $(5 \mathrm{hmC}, 5 \mathrm{fC}$, and $5 \mathrm{caC}$ ) can exert functions beyond mediating DNA demethylation, acting as marks that recruit chromatin-bound regulatory proteins.

neurons, where it comprises $\sim 40 \%$ of the level of $5 \mathrm{mC}$ (Kriaucionis and Heintz 2009), as well as in other neurons in the brain (Szulwach et al. 2011b; Mellen et al. 2012; Hahn et al. 2013) —indicating that like $5 \mathrm{mC}$ itself, oxidized methylcytosines are likely to function as epigenetic marks. Indeed, many oxi-mC "readers" have been identified by mass spectrometry (Spruijt et al. 2013); these include diverse transcription factors and chromatin regulatory proteins, but the importance of oxi-mC recognition for gene regulation remains to be defined.

\section{Passive Dilution of the Oxidized Base during Replication}

Blocking the action of the maintenance DNMTs would result in loss of DNA methylation during replication, a process known as passive DNA demethylation (Fig. 2). Conversion of $5 \mathrm{mC}$ to $5 \mathrm{hmC}$ could promote passive demethylation as a consequence of replication by inhibiting the ability of DNMT1 to recognize $5 \mathrm{hmCpGs}$ as observed in vitro (Valinluck and Sowers 2007). However, the obligate DNMT1 partner UHRF1 is reported to bind $5 \mathrm{mC}$ and $5 \mathrm{hmC}$ with similar affinities (Frauer et al. 2011), indicating that further investigation is needed. Current in vivo evidence from preimplantation embryos suggests that $5 \mathrm{hmC}$ is passively removed through replication (Inoue and Zhang 2011). Passive dilution of 5hmC has also been reported in primordial germ cells (PGCs) during the second wave of DNA demethylation observed in these cells (Hackett et al. 2013). Notably, 5hmC levels are dramatically reduced during in vitro expansion of activated mouse $\mathrm{CD}^{+}$and $\mathrm{CD}^{+} \mathrm{T}$ cells (Tsagaratou and Rao, unpubl.) as well as in many cancers (Ko et al. 2010; Pfeifer et al. 2013) and normal proliferating tissues (Pfeifer et al. 2013), suggesting that passive $5 \mathrm{hmC}$ dilution occurs in these cases as well.

\section{Active DNA Demethylation through DNA Repair}

The DNA repair enzyme TDG (thymine DNA glycosylase) was originally identified as recognizing and repairing $\mathrm{T}: \mathrm{G}$ mismatches in DNA. However, TDG also efficiently excises $5 \mathrm{fC}$ and $5 \mathrm{caC}$ that are properly paired to $\mathrm{G}$ in double-strand DNA (Fig. 2) (He et al. 2011), and depletion of TDG in ES cells results in increased levels of $5 \mathrm{fC}$ and $5 \mathrm{caC}$ at specific genomic locations (Shen et al. 2013; Song et al. 2013). Consistent with the hypothesis that TDG-mediated excision of $5 \mathrm{fC}$ and $5 \mathrm{caC}$ constitutes the last step of a pathway of TET-mediated active DNA demethylation, TDG is required for embryonic develop- 
ment and TDG-null embryos as well as embryos that bear a catalytically inactive mutation of TDG and show epigenetic abnormalities, with predominant reduction in the expression of Hox genes because of aberrant methylation observed in their regulatory sequences (Cortazar et al. 2011; Cortellino et al. 2011).

\section{BIOLOGICAL FUNCTIONS OF TET PROTEINS AND 5HMC}

TET enzymes are widely expressed, with at least one member being represented in every cell type examined. Tet 1 and Tet 2 are the two major TET proteins expressed in mouse ES cells, whereas Tet3 is barely expressed (Fig. 3); Tet 1 and Tet 2 are also high in PGCs and in the inner cell mass of the mouse embryo from which ES cells are derived. Tet 1 mRNA expression drops rapidly in differentiating mouse ES cells (Koh et al. 2011), whereas Tet2 protein levels are regulated by Idax during ES cell differentiation (Ko et al. 2013). Tet 2 and Tet 3 are the major TET proteins expressed in differentiated tissues and cell types (Fig. 3). Tet1-deficient mice on a pure C57BL/6 genetic background are born below Mendelian ratios and display female sterility (Kang and Rao, unpubl.) and Tet2-deficient mice are viable and fertile (Ko et al. 2011) with a mild hematopoietic phenotype, whereas Tet3-deficient mice are perinatally lethal (Gu et al. 2011; Li and Rao, unpubl.).

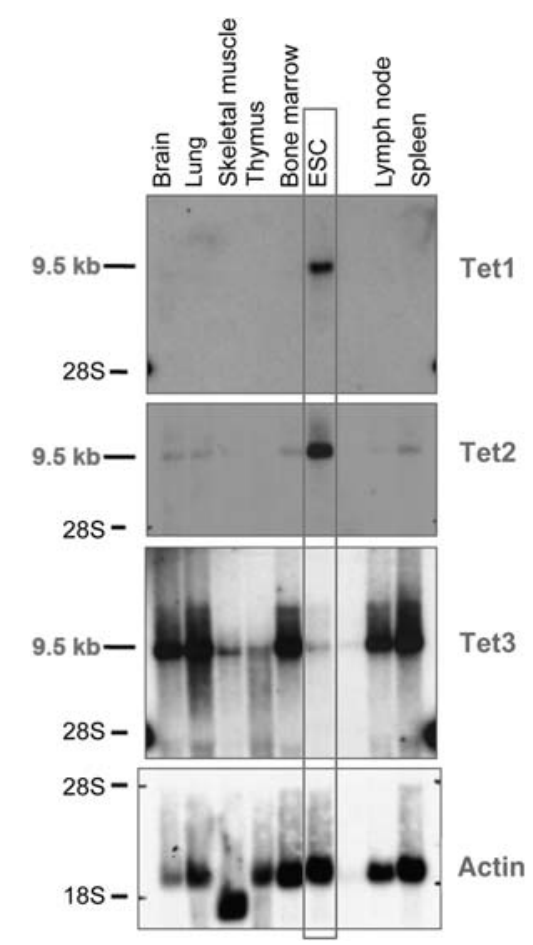

Figure 3. Northern blot analysis of TET mRNA expression in different murine tissues. Probes for actin were used for normalization. Mouse embryonic stem cells (ESCs), which primarily express Tet 1 and Tet 2 , are highlighted. Tet 3 is not expressed in ESC but is abundantly expressed in all of the differentiated cell types.
There have been extensive studies of $5 \mathrm{hmC}$ distribution in $\mathrm{ES}$ cells and brain. $5 \mathrm{hmC}$ is found predominantly in euchromatic regions, suggesting that it is associated with gene activity (Ficz et al. 2011). In mouse ES cells, Tet 1 and $5 \mathrm{hmC}$ are enriched at gene bodies, TSSs, promoters, and genomic regions with moderate $\mathrm{CpG}$ density (Ficz et al. 2011; Pastor et al. 2011; Williams et al. 2011; Wu et al. 2011a,b; Xu et al. 2011). CGIs that bind Tet1 in undifferentiated ES cells show an increase in $5 \mathrm{mC}$ upon Tet 1 deletion (Wu et al. 2011a), implicating Tet1 in maintaining CGI hypomethylation (Williams et al. 2012), either by blocking the DNA methylation machinery or by promoting DNA demethylation. There is also evidence for specific enrichment of $5 \mathrm{hmC}$ at "bivalent" gene promoters marked with H3K4me3 and H3K27me3 histone modifications, associated with transcriptionally active and silenced genes, respectively (Gu et al. 2011; Pastor et al. 2011; Williams et al. 2011; Wu et al. 2011a). This dual modification is thought to mark genes that are poised for activation in response to an external signal (Bernstein et al. 2006). Finally, $5 \mathrm{hmC}$ is located at many intergenic cisregulatory elements such as active enhancers, pluripotent transcription factor-binding sites, and insulator-binding sites (Ficz et al. 2011; Pastor et al. 2011; Wu et al. 2011a; Yu et al. 2012); indeed LMRs, which correspond generally to gene-distal regulatory elements, show enrichment for TET1 binding and 5hmC (Stadler et al. 2011).

The presence of $5 \mathrm{hmC}$ in gene bodies correlates with gene expression in mouse and human ES cells (Ficz et al. 2011; Pastor et al. 2011; Stroud et al. 2011; Szulwach et al. 2011a; Wu et al. 2011a; Xu et al. 2011); in neural cells (Mellen et al. 2012) during neurogenesis, where the gain of $5 \mathrm{hmC}$ is accompanied by loss of $\mathrm{H} 3 \mathrm{~K} 27 \mathrm{me} 3$ at promoters and gene bodies (Hahn et al. 2013); in mouse and human melanomas (Lian et al. 2012); in diverse other cell types and tissues including thymocytes and peripheral T cells (Tsagaratou and Rao, unpubl.). On the basis of our studies in undifferentiated mouse ES cells (Koh et al. 2011; Huang et al. 2014), it seems likely that Tet2 is primarily responsible for depositing gene-body $5 \mathrm{hmC}$. Briefly, the use of ES cells depleted of either Tet1 or Tet 2 showed that Tet 1 primarily regulated $5 \mathrm{hmC}$ levels at promoter/TSS regions, whereas Tet 2 primarily regulated $5 \mathrm{hmC}$ in the gene bodies of highly expressed genes (Huang et al. 2014). This difference may reflect the fact that Tet 1 possesses a CXXC domain that would be expected to bind unmethylated CpGs and therefore would be targeted to $\mathrm{CpG}$ islands and high $\mathrm{CpG}$ promoters, as is in fact observed (Wu and Zhang 2011; Williams et al. 2012 ); in contrast, Tet 2 would not be expected to be targeted preferentially to promoters because IDAX, the separated CXXC domain of Tet2, is not expressed in undifferentiated ES cells (Fig. 1B) (Ko et al. 2013). The ability of Tet 2 to control $5 \mathrm{hmC}$ deposition at gene bodies may reflect its reported association with the SET1/COMPASS complex (Deplus et al. 2013) that travels with RNA polymerase II (Shilatifard 2012). Overall, Tet1 and Tet2 have distinct as well as redundant functions in mouse ES cells; similarly, Tet 2 and Tet 3 may have some overlapping as well as distinct functions in differentiated cell 
types, including T cells and hematopoietic precursor cells (Tsagaratou and Rao, unpubl.).

\section{DNA METHYLATION, TET PROTEINS, AND 5hmC IN T CELLS}

It is well established that gene expression in T cells, as in other cell types, is influenced by DNA methylation: (1) Genes such as $C d 4$ are sequentially activated and repressed during different stages of T-cell development, in a manner thought to be epigenetically controlled (Taniuchi et al. 2002). (2) The up-regulation of Lck gene transcription from the DN1 to the DN3 stage of thymic development is correlated with progressive demethylation of CpGs in Lck exon 1 through intron 2 ( Ji et al. 2010). (3) Naive CD4 T cells show an impressive plasticity and readily differentiate to Th1, Th2, and Th17 cells depending on the cytokine milieu and the environmental cues (inflammatory stimuli, micro-organisms) that they receive (Ansel et al. 2003; Zhou et al. 2009; Mukasa et al. 2010). Demethylation within the transcribed sequences of Il4 and Ifng correlates with high expression levels of these cytokines in Th2 and Th1 cells, respectively (Lee et al. 2002; Ansel et al. 2006). (4) A small region in the promoter-enhancer of the interleukin-2 (Il2) gene is demethylated in T cells following activation (Bruniquel and Schwartz 2003). Demethylation occurs rapidly after transcriptional activation, suggesting that it may involve an active process independent of DNA replication (Bruniquel and Schwartz 2003; Murayama et al. 2006). Il2 promoter demethylation stabilizes Oct1 binding and ensures that secondary activation is more rapid and intense (Murayama et al. 2006). (5) Naive T cells that lack expression of the DNA methyltransferase DNMT1 up-regulate sets of cytokines that are normally silenced and methylated (Lee et al. 2001), whereas Dnmt1-null CD8 T cells aberrantly up-regulate CD4 T-cell cytokines (Makar and Wilson 2004). (6) The methylation status of conserved noncoding sequence 2 (CNS2) in the first intron of the Foxp3 gene influences the stability of Foxp3 expression in the regulatory T-cell (Treg) lineage. The transcription factor Runx 1 and its obligate partner, core-binding factor $\beta(\operatorname{Cbf} \beta)$, bind to this locus in conjunction with rapid demethylation, providing a window for Foxp3 binding; this in turn stabilizes lineage progression over ensuing cell divisions in an autoregulatory loop (Zheng et al. 2010). The conclusion is that localized loss of DNA methylation at promoter-enhancer regions is associated not only with transcription factor binding but also with stabilization of DNA-protein interactions to ensure robust expression of target genes after their activation.

We previously showed that all three Tet proteins are expressed in $\mathrm{CD}^{+}{ }^{+} \mathrm{CD}^{+}$double-positive (DP) thymocytes as well as CD4 single-positive (SP) and CD8 SP thymocytes (Ko et al. 2010). 5hmC levels in DP cells are lower than in CD4 and CD8 SP cells (0.7 compared with $2.5-3 \mathrm{pmol} 5 \mathrm{hmC} / \mu \mathrm{g}$ DNA, respectively); Th1 and Th2 cells derived from naive CD4 T cells and effector cytolytic $\mathrm{T}$ cells derived from naive CD8 $\mathrm{T}$ cells have even lower levels of $5 \mathrm{hmC}$ (Tsagaratou ko, and Rao, unpubl.). Global or conditional deletion of individual Tet proteins in T cells (using Tet $2^{-/-}$mice and Tet $3 f l /$ $\mathrm{fl}$ CD4Cre mice) resulted in relatively normal T-cell development and function, but $\mathrm{T}$ cells that lacked Tet3 showed compensatory up-regulation of Tet 2 mRNA (Tsagaratou and Rao, unpubl.). Thus, for a full understanding of T function in T cells, it will be necessary to analyze the phenotypes of Tet $2^{-/-}$Tet 3 flx $/$ flx CD4cre mice, which lack both Tet 2 and Tet 3 in T cells.

\section{METHODS FOR DETECTION AND MAPPING OF 5mc AND oxi-mC}

Several methods have been developed to map modified cytosine species in the genome (summarized in Table 1). They can be roughly divided into affinity-based approaches for enriching genomic regions that contain the modified cytosines and methods for mapping the modified bases at single-nucleotide resolution (Song et al. 2012; Pastor et al. 2013; Wu and Zhang 2014). We describe some of the most useful methods here; commercial kits have been developed for hME-Seal, TAB-seq, and oxidative bisulfite (oxBS).

\section{Affinity Approaches}

Immunoprecipitation of modified cytosines. The development of specific antibodies for each of the known modified cytosines $-5 \mathrm{mC}, 5 \mathrm{hmC}, 5 \mathrm{caC}$, and $5 \mathrm{fC}-\mathrm{en}-$ abled the immunoprecipitation (IP) and sequencing of genomic regions enriched for these modifications (Ficz et al. 2011; Williams et al. 2011; Wu et al. 2011a; Shen et al. 2013). The methylated DNA-IP (MeDIP) approach allows enrichment of methylated DNA by using an antibody that specifically recognizes methylated cytosines, whether or not they are in a $\mathrm{CpG}$ context (Weber et al. 2005). The DNA is denatured to convert it to a singlestrand form, thus exposing the $5 \mathrm{mCs}$ to permit efficient IP of genomic fragments enriched for $5 \mathrm{mC}$ (Weber et al. 2005). In all these cases, the efficiency of IP is markedly density dependent, and the methods described below are preferred for $5 \mathrm{hmC}$ mapping (Pastor et al. 2013).

Table 1. Summary of the available methods used to detect $5 \mathrm{mC}$ and oxi-mCs

\begin{tabular}{lll}
\hline Base & Affinity-based approach & $\begin{array}{c}\text { Single-nucleotide } \\
\text { resolution }\end{array}$ \\
\hline $5 \mathrm{mC}$ & MeDIP & WGBS, RRBS \\
$5 \mathrm{hmC}$ & CMS-IP, GLIB, 5hmC-IP, & TAB-seq, oxBS-seq, \\
& hMe-Seal, JBP1 IP & oxRRBS \\
$5 \mathrm{fC}$ & $5 \mathrm{fC}-\mathrm{IP}, 5 \mathrm{fC}-$ pull-down, & fCAB-seq \\
& $5 \mathrm{fC}-$ Seal & caCAB-seq \\
$5 \mathrm{caC}$ & $5 \mathrm{caC}$ IP &
\end{tabular}

MeDIP, methylated DNA IP; WGBS, whole-genome bisulfite sequencing; RRBS, reduced-representation bisulfite sequencing; CMS, cytosine methylenesulfonate; GLIB, glucosylation, periodate oxidation, biotinylation; hMe-Seal, 5-hmC selective chemical labeling; TAB-seq, TET assisted bisulfite sequencing; oxBS-seq, oxidative bisulfite sequencing; 5fC-Seal, 5fC selective chemical labeling; CAB-seq, chemically assisted bisulfite sequencing. 
Biotin modification of $5 \mathrm{hmC}$ followed by streptavidin pull-down. The enzyme $\beta$-glucosyl transferase from phage T4 very efficiently attaches glucose to the hydroxyl group of $5 \mathrm{hmC}$, after which the glucose can be modified by oxidation with sodium periodate, followed by treatment with an aldehyde-reactive probe in a method termed GLIB (glucosylation, periodate oxidation, biotinylation) (Pastor et al. 2011, 2012). A similar method that uses click chemistry to attach the biotin has been developed ( $5 \mathrm{hmC}$ selective chemical labeling, hMe-Seal [Song et al. 2011, 2012]).

IP of the 5hmC derivative, cytosine 5-methylenesulfonate. This method takes advantage of the fact that treatment of DNA with sodium bisulfite efficiently converts $5 \mathrm{hmC}$ in single-strand DNA to a stable and highly antigenic derivative, cytosine 5-methylenesulfonate (CMS) (Ko et al. 2010). Antibodies to CMS can thus be used to immunoprecipitate and sequence $5 \mathrm{hmC}$ containing fragments of genomic DNA with high specificity and low background; the method is much less density dependent than IP with antibodies to $5 \mathrm{hmC}$ itself (Pastor et al. 2011; Huang et al. 2012). Numerous studies have used this method to map 5 hmC efficiently in different systems (Pastor et al. 2011; Jeong et al. 2013; Lister et al. 2013; Vincent et al. 2013; Huang et al. 2014).

\section{Single-Nucleotide Resolution Approaches}

Most single-base-resolution methods used to map oxi$\mathrm{mC}$ species involve a step of treatment of the DNA with sodium bisulfite. Bisulfite treatment has long been used to distinguish unmodified cytosine from $5 \mathrm{mC}$, because it results in the deamination of unmodified cytosine to uracil, which is subsequently read as thymine after polymerase chain reaction (PCR) amplification. In contrast, methylated cytosines (and CMS) are resistant to bisulfite conversion and are read as cytosines, enabling quantitative discrimination between unmodified cytosines and $5 \mathrm{mC}$ (Frommer et al. 1992). It is now recognized, however, that bisulfite treatment cannot distinguish $5 \mathrm{mC}$ from $5 \mathrm{hmC}$ or $\mathrm{C}$ from $5 \mathrm{fC}$ and $5 \mathrm{caC}$ (Fig. 4A; Table 2).

\section{A}

\begin{tabular}{|c|c|c|c|c|}
\hline C & $5 \mathrm{caC}$ & $5 f C$ & $5 \mathrm{hmC}$ & $5 \mathrm{mC}$ (methylated) \\
\hline \multicolumn{3}{|c|}{ C (unmodified) } & & $5 \mathrm{mC}$ (methylated) \\
\hline C & $5 \mathrm{caC}$ & $5 \mathrm{fC}$ & $5 \mathrm{hmC}$ & $5 \mathrm{mC}$ (methylated) \\
\hline
\end{tabular}

Actual situation

Bisulfite sequencing

B

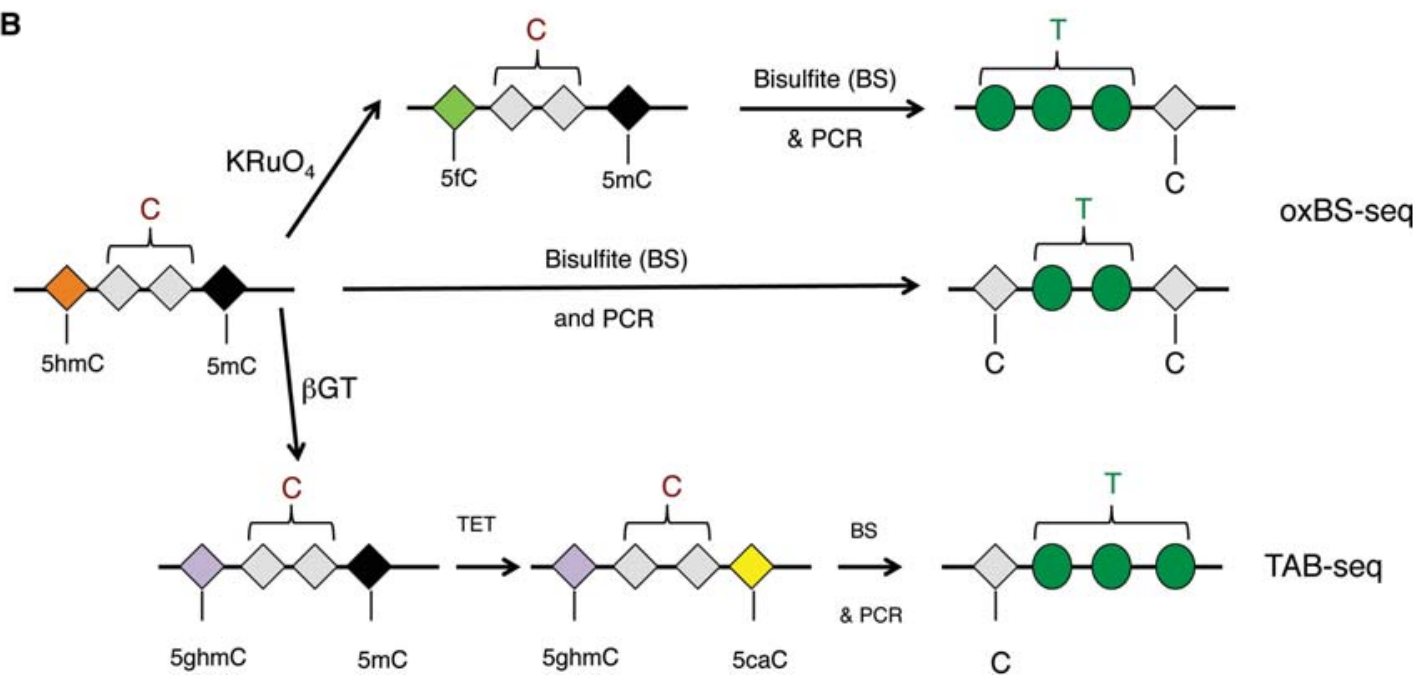

Figure 4. (A, top) Bisulfite sequencing (BS-seq) cannot discriminate methylated $\mathrm{C}$ from $5 \mathrm{hmC}$, because both remain unconverted after bisulfite treatment and PCR amplification. (Middle) The actual state of $\mathrm{C}$ in the genome can be unmethylated $\mathrm{C}, 5 \mathrm{caC}, 5 \mathrm{fC}, 5 \mathrm{hmC}$, or $5 \mathrm{mC}$. (Bottom) The advent of oxidative bisulfite (oxBS) sequencing, which introduces chemical treatment of DNA before the bisulfite treatment, allows discrimination of $5 \mathrm{hmC}$ from $5 \mathrm{mC}$; however, the unmodified $\mathrm{C}$ is still not distinguished from $5 \mathrm{caC}$ or $5 \mathrm{fC}$. $(B)$ Schematic representation of oxBS-seq and TAB-seq, two methods that enable detection of $5 \mathrm{hmC}$ at single-nucleotide resolution when combined with bisulfite sequencing. In the oxBS approach (top), DNA is treated with potassium perruthenate $\left(\mathrm{KRuO}_{4}\right)$ that oxidizes $5 \mathrm{hmC}$ to $5 \mathrm{fC}$. Subsequent bisulfite treatment converts $5 \mathrm{fC}$ (as well as $5 \mathrm{caC}$ and $\mathrm{C}$ ) to U that will be read as T after PCR amplification, so only $5 \mathrm{mC}$ stays unconverted and is thus read as C after PCR amplification. In contrast, in DNA samples that have been subjected exclusively to bisulfite treatment, both $5 \mathrm{hmC}$ and $5 \mathrm{mC}$ are read as $\mathrm{C}$ after PCR amplification, so $5 \mathrm{mC}$, $5 \mathrm{hmC}$, and "unmodified" C can be discriminated by subtracting the results of BS-seq from those of oxBS. In TAB-seq (TET-assisted bisulfite sequencing), the DNA is treated with T2 phage $\beta$-glucosyltransferase ( $\beta$ GT) that specifically recognizes and glycosylates $5 \mathrm{hmC}$, generating glucosylated $5 \mathrm{hmC}$ $(5 \mathrm{ghmC})$. Subsequent treatment with purified and active TET1 leads to oxidization of $5 \mathrm{mC}$ to $5 \mathrm{caC}$, and finally, treatment of the sample with bisulfite results in complete conversion of all the bases to U, read as T after PCR amplification, with the exception of $5 \mathrm{ghmC}$ that stays unconverted and thus is read as C. 
Table 2. Behavior of $5 \mathrm{mC}$ and its oxi-mCs in bisulfite conversion and the following PCR step

\begin{tabular}{lcc}
\hline Base & Bisulfite conversion & BS sequencing result \\
\hline $5 \mathrm{mC}$ & $5 \mathrm{mC}$ & $\mathrm{C}$ \\
$5 \mathrm{hmC}$ & $\mathrm{CMS}$ & $\mathrm{C}$ \\
$5 \mathrm{gmC}$ & $5 \mathrm{gmC}$ & $\mathrm{C}$ \\
$5 \mathrm{fC}$ & $\mathrm{U}$ & $\mathrm{T}$ \\
$5 \mathrm{caC}$ & $\mathrm{U}$ & $\mathrm{T}$ \\
$\mathrm{C}$ & $\mathrm{U}$ & $\mathrm{T}$ \\
\hline
\end{tabular}

CMS, cytosine, methylenesulfonate; $5 \mathrm{gmC}$, i.e., cytosine 5- $\beta$-glucosyl-5hydroxymethylcytosine.

$\boldsymbol{T A B}$-seq. TET-assisted BS-seq has been used to map $5 \mathrm{hmC}$ quantitatively at single-base resolution ( $\mathrm{Yu}$ et al. 2012). In this method, treatment with $\beta$ GT blocks $5 \mathrm{hmC}$, and subsequently, recombinant mouse TET1 is used to convert $5 \mathrm{mC}$ to oxi-mC-ideally, all the way to $5 \mathrm{caC}$ (Fig. 4B). $5 \mathrm{caC}$ (originally $5 \mathrm{mC}$ ) and unmodified $\mathrm{C}$ are both converted by bisulfite treatment to uracil; thus, the only base that is read as cytosine is the glucosylated $5 \mathrm{hmC}$ (Fig. 4B). The main caveat of this approach is that highly active TET enzyme is required for efficient conversion of $5 \mathrm{mC}$ to $5 \mathrm{caC}$ : If the conversion is inefficient such that there is no conversion of the $5 \mathrm{mC}$ or the conversion does not proceed beyond $5 \mathrm{hmC}$, there will be false-positive base calling of $5 \mathrm{hmC}$ at sites that were actually $5 \mathrm{mC}$. Bisulfite treatment can also be inefficient: Even with a high efficiency of $5 \mathrm{mC}$ oxidation by TET1 at sites with $80 \%-100 \% 5 \mathrm{mC}$, if only $95 \%$ of the unmodified $\mathrm{C}$ is converted to uracil, the remaining $5 \%$ of unconverted $5 \mathrm{mCs}$ will be falsely identified as $5 \mathrm{hmC}(\mathrm{Yu}$ et al. 2012).

Oxidative bisulfite sequencing. This is a chemical conversion method that also allows the quantitative mapping of $5 \mathrm{hmC}$ in genomic DNA at single-nucleotide resolution. Potassium perruthenate selectively oxidizes $5 \mathrm{hmC}$ to $5 \mathrm{fC}$, and subsequent bisulfite treatment of the DNA converts $5 \mathrm{fC}$ to $\mathrm{U}$ (Fig. 4B). By comparing the data from oxidized and bisulfite-treated DNA with those from only bisulfite-treated DNA, it is possible to distinguish $5 \mathrm{mC}$, $5 \mathrm{hmC}$, and unmodified $\mathrm{C}$ from one another. However, bases that are read as $\mathrm{T}$ can be derived from unmodified C, $5 \mathrm{fC}$, or $5 \mathrm{caC}$ (Booth et al. 2012). The method is more cost effective than TAB-seq; however, one needs to be cautious, because the method is very sensitive to contaminants in the isolated genomic DNA (Booth et al. 2013) and also tends to damage DNA, resulting in biases because of overamplification.

IP of the 5hmC derivative CMS. An advantage of the IP of the $5 \mathrm{hmC}$ derivative CMS (CMS-IP) method is that the modification status of cytosines in the immunoprecipitated DNA fragments can be estimated by determining whether they are read as $\mathrm{T}$ (i.e., were originally $\mathrm{C}, 5 \mathrm{fC}$, or $5 \mathrm{caC}$ ) or remain as $\mathrm{C}$ (in which case they were originally $5 \mathrm{mC}$ or $5 \mathrm{hmC}$ converted to CMS). Moreover, the input DNA can be analyzed by BS-seq to yield the methylation status of all cytosines in the genome.

\section{Effect of Sequencing Depth on Mapping Performance}

Because of the relatively low levels of $5 \mathrm{hmC}$ in the genome, high coverage is needed to sequence this base quantitatively. Furthermore, for the oxBS and TAB-seq single-base resolution methods, a subtraction is needed to obtain the actual levels of $5 \mathrm{hmC}$. As a result, there is an increase in the "noise level," thus further increasing the need to increase both coverage and the number of biological replicates.

In our experience and at current sequencing costs, a range of $\sim 30$ million reads per sample for MeDIP-seq, CMS-IP, and hMe-Seal constitutes a viable compromise between breadth and depth of sequencing. In contrast, whole-genome bisulfite sequencing and oxBS provide comprehensive genomic coverage at the cost of having to sequence more than a billion reads per sample, which increases the cost of the experiment tremendously. An alternative approach would be to combine TAB-seq and oxBS-seq with reduced-representation bisulfite sequencing (RRBS), which allows selective, but deep, sequencing of a fraction of the genome that is highly enriched for CpG islands (Meissner et al. 2008); in this case, only $\sim 25$ million 40-bp short reads are required to achieve an average sequencing depth of $\sim 120 \times$ by combining oxBSSeq with RRBS (oxRRBS) (Booth et al. 2012), making this method cost efficient and suitable for some applications, although it captures only a fraction of $5 \mathrm{mC}$ and thus $5 \mathrm{hmC}$ sites in the genome $(<10 \%$ of the 28 million CpGs [Bock et al. 2010] and $\sim 11.5 \%$ of the dynamically active CpGs that overlap with differentially methylated and hydroxymethylated regions, e.g., during development or during different time points of differentiation/treatment with different substances [Ziller et al. 2013]).

Overall, in our opinion, an approach that is cost efficient without compromising the quality of the data and thus the confidence of the conclusions deduced would be to combine affinity-based approaches such as CMS-IP to assess $5 \mathrm{mC}$ and oxi-mC at a genome-wide level and then apply single-nucleotide resolution approaches to specific loci of interest.

\section{CONCLUSIONS}

The oxi-mC species, $5 \mathrm{hmC}, 5 \mathrm{fC}$, and $5 \mathrm{caC}$, are now established as important intermediates in DNA demethylation as well as potential epigenetic marks that regulate chromatin structure by recruiting interacting proteins. Despite extensive research in numerous biological systems, the physiological functions of these modifications remain elusive. For instance, what targets TET proteins to specific regions of DNA? Is the correlation of high genebody $5 \mathrm{hmC}$ with high gene expression merely a by-product of gene transcription or does the presence of $5 \mathrm{hmC}$ actually facilitate transcription? The large data sets that have been generated provide stimulating ideas but are far from providing conclusive information. The advent of new sequencing approaches, the increase in depth of sequencing coverage, the study of more biological systems 
in combination with detailed experimental strategies for monitoring gene expression, the use of incisive mouse models, and a strong focus on individual genes will allow us to gain a better understanding of the biological functions of TET proteins and the oxi-mC modifications that they generate, in the context of physiological development as well as disease.

\section{ACKNOWLEDGMENTS}

We apologize to those whose work could not be cited owing to space limitations. We thank Drs. Will Pastor and Elizabeth Thompson for the Northern analysis in Figure 3, and Drs. Tarmo Äijö, Nancy Huang, and Lukas Chavez for fruitful discussions. The work was supported by NIH grant AI44432 and a grant from the California Institute of Regenerative Medicine (RM1-01729) to A.R. A.T. is the recipient of an Irvington Postdoctoral Fellowship from the Cancer Research Institute.

\section{REFERENCES}

Ansel KM, Lee DU, Rao A. 2003. An epigenetic view of helper T cell differentiation. Nat Immunol 4: 616-623.

Ansel KM, Djuretic I, Tanasa B, Rao A. 2006. Regulation of Th2 differentiation and Il4 locus accessibility. Annu Rev Immunol 24: 607-656.

Avvakumov GV, Walker JR, Xue S, Li Y, Duan S, Bronner C, Arrowsmith CH, Dhe-Paganon S. 2008. Structural basis for recognition of hemi-methylated DNA by the SRA domain of human UHRF1. Nature 455: 822-825.

Bernstein BE, Mikkelsen TS, Xie X, Kamal M, Huebert DJ, Cuff J, Fry B, Meissner A, Wernig M, Plath K, et al. 2006. A bivalent chromatin structure marks key developmental genes in embryonic stem cells. Cell 125: 315-326.

Bestor T, Laudano A, Mattaliano R, Ingram V. 1988. Cloning and sequencing of a cDNA encoding DNA methyltransferase of mouse cells. The carboxyl-terminal domain of the mammalian enzymes is related to bacterial restriction methyltransferases. J Mol Biol 203: 971-983.

Bock C, Tomazou EM, Brinkman AB, Muller F, Simmer F, Gu H, Jager N, Gnirke A, Stunnenberg HG, Meissner A. 2010. Quantitative comparison of genome-wide DNA methylation mapping technologies. Nat Biotechnol 28: 1106-1114.

Booth MJ, Branco MR, Ficz G, Oxley D, Krueger F, Reik W, Balasubramanian S. 2012. Quantitative sequencing of 5methylcytosine and 5-hydroxymethylcytosine at single-base resolution. Science 336: 934-937.

Booth MJ, Ost TW, Beraldi D, Bell NM, Branco MR, Reik W, Balasubramanian S. 2013. Oxidative bisulfite sequencing of 5-methylcytosine and 5-hydroxymethylcytosine. Nat Protoc 8: $1841-1851$.

Bruniquel D, Schwartz RH. 2003. Selective, stable demethylation of the interleukin-2 gene enhances transcription by an active process. Nat Immunol 4: 235-240.

Cortazar D, Kunz C, Selfridge J, Lettieri T, Saito Y, MacDougall E, Wirz A, Schuermann D, Jacobs AL, Siegrist F, et al. 2011. Embryonic lethal phenotype reveals a function of TDG in maintaining epigenetic stability. Nature 470: 419-423.

Cortellino S, Xu J, Sannai M, Moore R, Caretti E, Cigliano A, Le Coz M, Devarajan K, Wessels A, Soprano D, et al. 2011. Thymine DNA glycosylase is essential for active DNA demethylation by linked deamination-base excision repair. Cell 146: $67-79$.

Deaton AM, Bird A. 2011. CpG islands and the regulation of transcription. Genes Dev 25: 1010-1022.

Deplus R, Delatte B, Schwinn MK, Defrance M, Mendez J, Murphy N, Dawson MA, Volkmar M, Putmans P, Calonne
E, et al. 2013. TET2 and TET3 regulate GlcNAcylation and H3K4 methylation through OGT and SET1/COMPASS. EMBO J 32: 645-655.

Ficz G, Branco MR, Seisenberger S, Santos F, Krueger F, Hore TA, Marques CJ, Andrews S, Reik W. 2011. Dynamic regulation of 5-hydroxymethylcytosine in mouse ES cells and during differentiation. Nature 473: 398-402.

Frauer C, Hoffmann T, Bultmann S, Casa V, Cardoso MC, Antes I, Leonhardt H. 2011. Recognition of 5-hydroxymethylcytosine by the Uhrf1 SRA domain. PLoS One 6: e21306.

Frommer M, McDonald LE, Millar DS, Collis CM, Watt F, Grigg GW, Molloy PL, Paul CL. 1992. A genomic sequencing protocol that yields a positive display of 5-methylcytosine residues in individual DNA strands. Proc Natl Acad Sci 89: $1827-1831$

Gifford CA, Ziller MJ, Gu H, Trapnell C, Donaghey J, Tsankov A, Shalek AK, Kelley DR, Shishkin AA, Issner R, et al. 2013. Transcriptional and epigenetic dynamics during specification of human embryonic stem cells. Cell 153: 1149-1163.

Gu TP, Guo F, Yang H, Wu HP, Xu GF, Liu W, Xie ZG, Shi L, He $\mathrm{X}$, Jin SG, et al. 2011. The role of Tet3 DNA dioxygenase in epigenetic reprogramming by oocytes. Nature 477: 606-610.

Hackett JA, Sengupta R, Zylicz JJ, Murakami K, Lee C, Down TA, Surani MA. 2013. Germline DNA demethylation dynamics and imprint erasure through 5-hydroxymethylcytosine. Science 339: 448-452.

Hahn MA, Qiu R, Wu X, Li AX, Zhang H, Wang J, Jui J, Jin SG, Jiang Y, Pfeifer GP, et al. 2013. Dynamics of 5-hydroxymethylcytosine and chromatin marks in mammalian neurogenesis. Cell Rep 3: 291-300.

Hansen KD, Timp W, Bravo HC, Sabunciyan S, Langmead B, McDonald OG, Wen B, Wu H, Liu Y, Diep D, et al. 2011. Increased methylation variation in epigenetic domains across cancer types. Nat Genet 43: 768-775.

Hashimoto H, Horton JR, Zhang X, Bostick M, Jacobsen SE, Cheng X. 2008. The SRA domain of UHRF1 flips 5-methylcytosine out of the DNA helix. Nature 455: 826-829.

Hashimoto H, Pais JE, Zhang X, Saleh L, Fu ZQ, Dai N, Correa IR, Zheng Y, Cheng X. 2014. Structure of a Naegleria Tetlike dioxygenase in complex with 5-methylcytosine DNA. Nature 506: 391-395.

He YF, Li BZ, Li Z, Liu P, Wang Y, Tang Q, Ding J, Jia Y, Chen $\mathrm{Z}, \mathrm{Li} \mathrm{L}$, et al. 2011. Tet-mediated formation of 5-carboxylcytosine and its excision by TDG in mammalian DNA. Science 333: $1303-1307$.

Hu L, Li Z, Cheng J, Rao Q, Gong W, Liu M, Shi YG, Zhu J, Wang P, Xu Y. 2013. Crystal structure of TET2-DNA complex: Insight into TET-mediated $5 \mathrm{mC}$ oxidation. Cell 155: $1545-1555$.

Huang Y, Pastor WA, Martinez JK, Rao A. 2012. The anti-CMS method for genome-wide mapping of 5-hydroxymethylcytosine. Nature Prot 7: 1897-1908.

Huang Y, Chavez L, Chang X, Wang X, Pastor WA, Kang J, Zepeda-Martinez JA, Pape UJ, Jacobsen SE, Peters B, et al. 2014. Distinct roles of Tet 1 and Tet2 in mouse embryonic stem cells. Proc Natl Acad Sci 111: 1361-1366.

Inoue A, Zhang Y. 2011. Replication-dependent loss of 5hydroxymethylcytosine in mouse preimplantation embryos. Science 334: 194.

Ito S, Shen L, Dai Q, Wu SC, Collins LB, Swenberg JA, He C, Zhang Y. 2011. Tet proteins can convert 5-methylcytosine to 5-formylcytosine and 5-carboxylcytosine. Science 333: $1300-1303$.

Iyer LM, Anantharaman V, Wolf MY, Aravind L. 2008. Comparative genomics of transcription factors and chromatin proteins in parasitic protists and other eukaryotes. Int J Parasitol 38: $1-31$.

Iyer LM, Tahiliani M, Rao A, Aravind L. 2009. Prediction of novel families of enzymes involved in oxidative and other complex modifications of bases in nucleic acids. Cell Cycle 8: $1698-1710$.

Jeong M, Sun D, Luo M, Huang Y, Challen GA, Rodriguez B, Zhang X, Chavez L, Wang H, Hannah R, et al. 2014. Large 
conserved domains of low DNA methylation maintained by Dnmt3a. Nat Genet 46: 17-23.

Ji H, Ehrlich LI, Seita J, Murakami P, Doi A, Lindau P, Lee H, Aryee MJ, Irizarry RA, Kim K, et al. 2010. Comprehensive methylome map of lineage commitment from haematopoietic progenitors. Nature 467: 338-342.

Klose RJ, Bird AP. 2006. Genomic DNA methylation: The mark and its mediators. Trends Biochem Sci 31: 89-97.

Ko M, Huang Y, Jankowska AM, Pape UJ, Tahiliani M, Bandukwala HS, An J, Lamperti ED, Koh KP, Ganetzky R, et al. 2010. Impaired hydroxylation of 5-methylcytosine in myeloid cancers with mutant TET2. Nature 468: 839-843.

Ko M, Bandukwala HS, An J, Lamperti ED, Thompson EC, Hastie R, Tsangaratou A, Rajewsky K, Koralov SB, Rao A. 2011. Ten-Eleven-Translocation 2 (TET2) negatively regulates homeostasis and differentiation of hematopoietic stem cells in mice. Proc Natl Acad Sci 108: 14566-14571.

Ko M, An J, Bandukwala HS, Chavez L, Aijo T, Pastor WA, Segal MF, Li H, Koh KP, Lahdesmaki H, et al. 2013. Modulation of TET2 expression and 5-methylcytosine oxidation by the CXXC domain protein IDAX. Nature 497: 122-126.

Koh KP, Yabuuchi A, Rao S, Huang Y, Cunniff K, Nardone J, Laiho A, Tahiliani M, Sommer CA, Mostoslavsky G, et al. 2011. Tet 1 and Tet2 regulate 5-hydroxymethylcytosine production and cell lineage specification in mouse embryonic stem cells. Cell Stem Cell 8: 200-213.

Kohli RM, Zhang Y. 2013. TET enzymes, TDG and the dynamics of DNA demethylation. Nature 502: 472-479.

Kriaucionis S, Heintz N. 2009. The nuclear DNA base 5hydroxymethylcytosine is present in Purkinje neurons and the brain. Science 324: 929-930.

Kulis M, Heath S, Bibikova M, Queiros AC, Navarro A, Clot G, Martinez-Trillos A, Castellano G, Brun-Heath I, Pinyol M, et al. 2012. Epigenomic analysis detects widespread genebody DNA hypomethylation in chronic lymphocytic leukemia. Nat Genet 44: 1236-1242.

Laurent L, Wong E, Li G, Huynh T, Tsirigos A, Ong CT, Low HM, Kin Sung KW, Rigoutsos I, Loring J, et al. 2010. Dynamic changes in the human methylome during differentiation. Genome Res 20: 320-331.

Lee PP, Fitzpatrick DR, Beard C, Jessup HK, Lehar S, Makar KW, Perez-Melgosa M, Sweetser MT, Schlissel MS, Nguyen $\mathrm{S}$, et al. 2001. A critical role for Dnmt1 and DNA methylation in $\mathrm{T}$ cell development, function, and survival. Immunity 15: $763-774$.

Lee DU, Agarwal S, Rao A. 2002. Th2 lineage commitment and efficient production involves extended demethylation of the IL-4 gene. Immunity 16: 649-660.

Lian CG, Xu Y, Ceol C, Wu F, Larson A, Dresser K, Xu W, Tan L, Hu Y, Zhan Q, et al. 2012. Loss of 5-hydroxymethylcytosine is an epigenetic hallmark of melanoma. Cell 150: 11351146.

Lister R, Pelizzola M, Dowen RH, Hawkins RD, Hon G, TontiFilippini J, Nery JR, Lee L, Ye Z, Ngo QM, et al. 2009. Human DNA methylomes at base resolution show widespread epigenomic differences. Nature 462: 315-322.

Lister R, Mukamel EA, Nery JR, Urich M, Puddifoot CA, Johnson ND, Lucero J, Huang Y, Dwork AJ, Schultz MD, et al. 2013. Global epigenomic reconfiguration during mammalian brain development. Science 341: 1237905.

Loenarz C, Schofield CJ. 2008. Expanding chemical biology of 2-oxoglutarate oxygenases. Nat Chem Biol 4: 152-156.

Loenarz C, Schofield CJ. 2011. Physiological and biochemical aspects of hydroxylations and demethylations catalyzed by human 2-oxoglutarate oxygenases. Trends Biochem Sci 36: $7-18$.

Lorsbach RB, Moore J, Mathew S, Raimondi SC, Mukatira ST, Downing JR. 2003. TET1, a member of a novel protein family, is fused to MLL in acute myeloid leukemia containing the t(10;11)(q22;q23). Leukemia 17: 637-641.

Makar KW, Wilson CB. 2004. DNA methylation is a nonredundant repressor of the Th2 effector program. J Immunol 173: $4402-4406$.
Meissner A, Mikkelsen TS, Gu H, Wernig M, Hanna J, Sivachenko A, Zhang X, Bernstein BE, Nusbaum C, Jaffe DB, et al. 2008. Genome-scale DNA methylation maps of pluripotent and differentiated cells. Nature 454: 766-770.

Mellen M, Ayata P, Dewell S, Kriaucionis S, Heintz N. 2012. $\mathrm{MeCP} 2$ binds to $5 \mathrm{hmC}$ enriched within active genes and accessible chromatin in the nervous system. Cell 151: 14171430.

Mukasa R, Balasubramani A, Lee YK, Whitley SK, Weaver BT, Shibata Y, Crawford GE, Hatton RD, Weaver CT. 2010. Epigenetic instability of cytokine and transcription factor gene loci underlies plasticity of the T helper 17 cell lineage. $\mathrm{Im}$ munity 32: 616-627.

Murayama A, Sakura K, Nakama M, Yasuzawa-Tanaka K, Fujita E, Tateishi Y, Wang Y, Ushijima T, Baba T, Shibuya $\mathrm{K}$, et al. 2006. A specific $\mathrm{CpG}$ site demethylation in the human interleukin 2 gene promoter is an epigenetic memory. EMBO J 25: 1081-1092.

Ono R, Taki T, Taketani T, Taniwaki M, Kobayashi H, Hayashi Y. 2002. LCX, leukemia-associated protein with a CXXC domain, is fused to MLL in acute myeloid leukemia with trilineage dysplasia having $\mathrm{t}(10 ; 11)(\mathrm{q} 22 ; \mathrm{q} 23)$. Cancer Res 62: $4075-4080$.

Ooi SK, O'Donnell AH, Bestor TH. 2009. Mammalian cytosine methylation at a glance. J Cell Sci 122: 2787-2791.

Pastor WA, Pape UJ, Huang Y, Henderson HR, Lister R, Ko M, McLoughlin EM, Brudno Y, Mahapatra S, Kapranov P, et al. 2011. Genome-wide mapping of 5-hydroxymethylcytosine in embryonic stem cells. Nature 473: 394-397.

Pastor WA, Huang Y, Henderson HR, Agarwal S, Rao A. 2012. The GLIB technique for genome-wide mapping of 5-hydroxymethylcytosine. Nat Protoc 7: 1909-1917.

Pastor WA, Aravind L, Rao A. 2013. TETonic shift: Biological roles of TET proteins in DNA demethylation and transcription. Nat Rev Mol Cell Biol 14: 341-356.

Pfeifer GP, Kadam S, Jin SG. 2013. 5-hydroxymethylcytosine and its potential roles in development and cancer. Epigenetics Chromatin 6: 10.

Shen L, Wu H, Diep D, Yamaguchi S, D’Alessio AC, Fung HL, Zhang K, Zhang Y. 2013. Genome-wide analysis reveals TET- and TDG-dependent 5-methylcytosine oxidation dynamics. Cell 153: 692-706.

Shilatifard A. 2012. The COMPASS family of histone H3K4 methylases: Mechanisms of regulation in development and disease pathogenesis. Annu Rev Biochem 81: 65-95.

Song CX, Szulwach KE, Fu Y, Dai Q, Yi C, Li X, Li Y, Chen CH, Zhang W, Jian X, et al. 2011. Selective chemical labeling reveals the genome-wide distribution of 5-hydroxymethylcytosine. Nat Biotechnol 29: 68-72.

Song CX, Yi C, He C. 2012. Mapping recently identified nucleotide variants in the genome and transcriptome. Nat Biotechnol 30: 1107-1116.

Song CX, Szulwach KE, Dai Q, Fu Y, Mao SQ, Lin L, Street C, Li Y, Poidevin M, Wu H, et al. 2013. Genome-wide profiling of 5-formylcytosine reveals its roles in epigenetic priming. Cell 153: 678-691.

Spruijt CG, Gnerlich F, Smits AH, Pfaffeneder T, Jansen PW, Bauer C, Munzel M, Wagner M, Muller M, Khan F, et al. 2013. Dynamic readers for 5-(hydroxy)methylcytosine and its oxidized derivatives. Cell 152: 1146-1159.

Stadler MB, Murr R, Burger L, Ivanek R, Lienert F, Scholer A, van Nimwegen E, Wirbelauer C, Oakeley EJ, Gaidatzis D, et al. 2011. DNA-binding factors shape the mouse methylome at distal regulatory regions. Nature 480: 490-495.

Stroud H, Feng S, Morey Kinney S, Pradhan S, Jacobsen SE. 2011. 5-Hydroxymethylcytosine is associated with enhancers and gene bodies in human embryonic stem cells. Genome Biol 12: R54.

Suzuki MM, Bird A. 2008. DNA methylation landscapes: Provocative insights from epigenomics. Nat Rev Genet 9: 465476.

Szulwach KE, Li X, Li Y, Song CX, Han JW, Kim S, Namburi S, Hermetz K, Kim JJ, Rudd MK, et al. 2011a. Integrating 5- 
hydroxymethylcytosine into the epigenomic landscape of human embryonic stem cells. PLoS Genet 7: e1002154.

Szulwach KE, Li X, Li Y, Song CX, Wu H, Dai Q, Irier H, Upadhyay AK, Gearing M, Levey AI, et al. 2011b. 5-hmCmediated epigenetic dynamics during postnatal neurodevelopment and aging. Nat Neurosci 14: 1607-1616.

Tahiliani M, Koh KP, Shen Y, Pastor WA, Bandukwala H, Brudno Y, Agarwal S, Iyer LM, Liu DR, Aravind L, et al. 2009. Conversion of 5-methylcytosine to 5-hydroxymethylcytosine in mammalian DNA by MLL partner TET1. Science 324: $930-935$.

Taniuchi I, Osato M, Egawa T, Sunshine MJ, Bae SC, Komori T, Ito Y, Littman DR. 2002. Differential requirements for Runx proteins in CD4 repression and epigenetic silencing during T lymphocyte development. Cell 111: 621-633.

Valinluck V, Sowers LC. 2007. Endogenous cytosine damage products alter the site selectivity of human DNA maintenance methyltransferase DNMT1. Cancer Res 67: 946-950.

Vincent JJ, Huang Y, Chen PY, Feng S, Calvopina JH, Nee K, Lee SA, Le T, Yoon AJ, Faull K, et al. 2013. Stage-specific roles for Tet1 and Tet2 in DNA demethylation in primordial germ cells. Cell Stem Cell 12: 470-478.

Weber M, Davies JJ, Wittig D, Oakeley EJ, Haase M, Lam WL, Schubeler D. 2005. Chromosome-wide and promoter-specific analyses identify sites of differential DNA methylation in normal and transformed human cells. Nat Genet 37: 853-862.

Williams K, Christensen J, Pedersen MT, Johansen JV, Cloos PA, Rappsilber J, Helin K. 2011. TET1 and hydroxymethylcytosine in transcription and DNA methylation fidelity. $\mathrm{Na}$ ture 473: 343-348.

Williams K, Christensen J, Helin K. 2012. DNA methylation: TET proteins-guardians of CpG islands? EMBO Rep 13: 28-35.

Wu H, Zhang Y. 2011. Tet1 and 5-hydroxymethylation: A genome-wide view in mouse embryonic stem cells. Cell Cycle 10: $2428-2436$.
Wu H, Zhang Y. 2014. Reversing DNA methylation: Mechanisms, genomics, and biological functions. Cell 156: 4568.

Wu H, D'Alessio AC, Ito S, Wang Z, Cui K, Zhao K, Sun YE, Zhang Y. 2011a. Genome-wide analysis of 5-hydroxymethylcytosine distribution reveals its dual function in transcriptional regulation in mouse embryonic stem cells. Genes Dev 25: 679-684.

Wu H, D'Alessio AC, Ito S, Xia K, Wang Z, Cui K, Zhao K, Sun YE, Zhang Y. 2011 b. Dual functions of Tet1 in transcriptional regulation in mouse embryonic stem cells. Nature 473: 389 393.

Xie W, Schultz MD, Lister R, Hou Z, Rajagopal N, Ray P, Whitaker JW, Tian S, Hawkins RD, Leung D, et al. 2013. Epigenomic analysis of multilineage differentiation of human embryonic stem cells. Cell 153: 1134-1148.

$\mathrm{Xu} \mathrm{Y,} \mathrm{Wu} \mathrm{F,} \mathrm{Tan} \mathrm{L,} \mathrm{Kong} \mathrm{L,} \mathrm{Xiong} \mathrm{L,} \mathrm{Deng} \mathrm{J,} \mathrm{Barbera} \mathrm{AJ,}$ Zheng L, Zhang H, Huang S, et al. 2011. Genome-wide regulation of $5 \mathrm{hmC}, 5 \mathrm{mC}$, and gene expression by Tet 1 hydroxylase in mouse embryonic stem cells. Mol Cell 42: $451-$ 464.

Yu M, Hon GC, Szulwach KE, Song CX, Zhang L, Kim A, Li X, Dai Q, Shen Y, Park B, et al. 2012. Base-resolution analysis of 5-hydroxymethylcytosine in the mammalian genome. Cell 149: $1368-1380$.

Zheng Y, Josefowicz S, Chaudhry A, Peng XP, Forbush K, Rudensky AY. 2010. Role of conserved non-coding DNA elements in the Foxp3 gene in regulatory T-cell fate. Nature 463: 808-812.

Zhou L, Chong MM, Littman DR. 2009. Plasticity of CD4+ T cell lineage differentiation. Immunity 30: 646-655.

Ziller MJ, Gu H, Muller F, Donaghey J, Tsai LT, Kohlbacher O, De Jager PL, Rosen ED, Bennett DA, Bernstein BE, et al. 2013. Charting a dynamic DNA methylation landscape of the human genome. Nature 500: 477-481. 


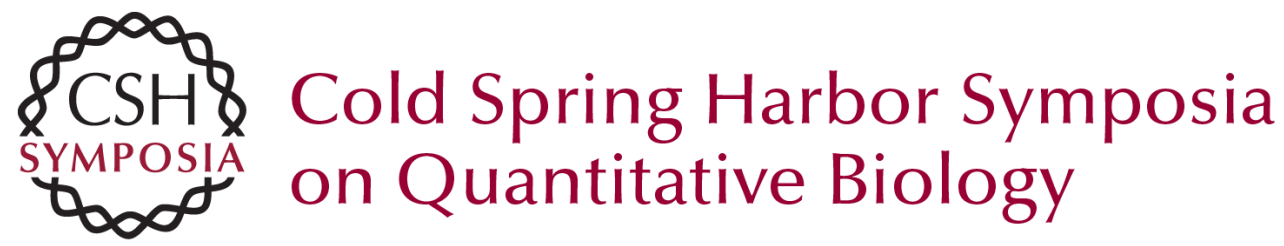

\section{TET Proteins and 5-Methylcytosine Oxidation in the Immune System}

Ageliki Tsagaratou and Anjana Rao

Cold Spring Harb Symp Quant Biol 2013 78: 1-10 originally published online March 11, 2014 Access the most recent version at doi:10.1101/sqb.2013.78.020248

References This article cites 89 articles, 21 of which can be accessed free at: http://symposium.cshlp.org/content/78/1.full.html\#ref-list-1

License

Email Alerting Receive free email alerts when new articles cite this article - sign up in Service the box at the top right corner of the article or click here. 